\title{
mGluR5 Antagonism Attenuates Methamphetamine Reinforcement and Prevents Reinstatement of Methamphetamine-Seeking Behavior in Rats
}

\author{
Justin T Gass', Megan PH Osborne', Noreen L Watson', Jordan L Brown' and M Foster Olive*,' \\ 'Department of Psychiatry and Behavioral Sciences, Center for Drug and Alcohol Programs, Medical University of South Carolina, \\ Charleston, SC, USA
}

\begin{abstract}
Addiction to methamphetamine is a significant public health problem, and there are currently no pharmacological agents that are approved for the treatment of addiction to this powerful psychostimulant. Chronic methamphetamine use leads to cognitive dysfunction as well as numerous psychiatric, neurological, and cardiovascular complications. There is a growing body of literature implicating an important role for glutamate neurotransmission in psychostimulant addiction. In the present study, we examined the effects of the selective type 5 metabotropic glutamate receptor (mGluR5) antagonist 3-((2-methyl-l,3-thiazol-4-yl)ethynyl)pyridine (MTEP) on intravenous self-administration of methamphetamine and reinstatement of methamphetamine-seeking behavior. Adult male SpragueDawley rats were trained to respond for intravenous methamphetamine $(0.1$ or $0.2 \mathrm{mg} / \mathrm{kg}$ per infusion) or food pellets and were subsequently administered vehicle or MTEP $(0.3-3 \mathrm{mg} / \mathrm{kg})$ before drug or food self-administration on a fixed-ratio I (FRI) schedule of reinforcement or a progressive ratio (PR) schedule of reinforcement. We also examined the effects of vehicle or MTEP (0.3-3 mg/kg) on cue- and drug-induced reinstatement of methamphetamine-seeking behavior as well as cue-induced reinstatement of food-seeking behavior. Our results show that MTEP dose dependently reduced the reinforcing effects of methamphetamine under FRI and PR schedules of reinforcement without altering overall responding for food. MTEP also dose dependently prevented cue- and drug-induced reinstatement of methamphetamine-seeking behavior, but did not alter cue-induced reinstatement of food-seeking behavior. Together, these results indicate that mGluR5 receptors mediate methamphetamine reinforcement and methamphetamine-seeking behavior, and that pharmacological inhibitors of mGluR5 receptor function may represent a novel class of potential therapeutic agents for the treatment of methamphetamine addiction.

Neuropsychopharmacology (2009) 34, 820-833; doi:I0.I038/npp.2008. I40; published online 17 September 2008
\end{abstract}

Keywords: methamphetamine; MTEP; mGluR5; self-administration; progressive ratio; reinstatement

\section{INTRODUCTION}

Methamphetamine is a potent and highly addictive psychomotor stimulant. According to recent epidemiological estimates, approximately $5.8 \%$ of people in the United States age 12 or older have used methamphetamine at least once in their lifetime, and use of the drug within the last month is estimated to occur in approximately $0.3 \%$ of the population (Maxwell and Rutkowski, 2008). These estimates also indicate that although the overall number of people using methamphetamine regularly has remained stable over the past 5 years, the number of people entering treatment for methamphetamine

*Correspondence: Dr MF Olive, Department of Psychiatry and Behavioral Sciences, Center for Drug and Alcohol Programs, Medical University of South Carolina, 67 President Street, MSC 86I, Charleston, SC 29425, USA, Tel: + I 843792 1229, Fax: + I 843 792 7353, E-mail: olive@musc.edu

Received 16 April 2008; revised 5 August 2008; accepted 6 August 2008 abuse and addiction has more than doubled in the same time period. There is a high degree of comorbidity of other psychiatric disorders in methamphetamine users, and chronic use of the drug leads to serious health consequences, including cardiovascular abnormalities, increased incidences of infectious diseases such as HIV and hepatitis C, and significant cognitive dysfunction (Barr et al, 2006; Darke et al, 2008; Lineberry and Bostwick, 2006; Meredith et al, 2005; Winslow et al, 2007). Current methods for the treatment for methamphetamine addiction include psychosocial or cognitive behavioral therapy in inpatient and outpatient settings (Lee and Rawson, 2008; Ling et al, 2006). In addition, numerous compounds have been studied in both humans and animals for potential use as therapeutic aids in the treatment of addiction to methamphetamine (Srisurapanont et al, 2001; Vocci and Appel, 2007). However, currently there are no therapeutic agents the have gained approval specifically for the treatment of methamphetamine addiction, and relapse rates remain high. 
Methamphetamine is a potent monoamine-releasing agent that increases dopamine, norepinephrine, and serotonin neurotransmission (Barr et al, 2006; Sulzer et al, 2005). Methamphetamine also increases the efflux of glutamate from intracellular stores (Abekawa et al, 1994; Bustamante et al, 2002; Nash and Maickel, 1999; Raudensky and Yamamoto, 2007; Rocher and Gardier, 2001; Shoblock et al, 2003; Stephans and Yamamoto, 1995), but most investigators have viewed methamphetamine-induced glutamate release as contributing to the neurotoxic effects of the drug rather than its reinforcing effects (Marshall et al, 1993; Ohmori et al, 1996; Stephans and Yamamoto, 1994; Tata and Yamamoto, 2007). However, there is a small body of literature suggesting that glutamate transmission is involved in the reinforcing effects of methamphetamine. Receptors for glutamate are classified as either ionotropic (such as the $N$-methyl-D-aspartate (NMDA), $\alpha$-amino-3-hydroxy-5-methyl-4-isoxazolepropionic acid (AMPA) and kainic acid receptor subtypes) or metabotropic (mGluRl-8) subtypes. Pharmacological blockade of NMDA receptors with MK-801 has been reported to inhibit the development of a methamphetamine conditioned place preference in mice (Kim and Jang, 1997), and the nonselective NMDA receptor antagonist dextromethorphan has been shown to decrease intravenous methamphetamine self-administration in rats (Glick et al, 2001; Jun and Schindler, 2000).

Given the preponderance of evidence suggesting a critical role for glutamatergic transmission in psychostimulant addiction (Gass and Olive, 2008; Kalivas, 2000, 2007; Tzschentke and Schmidt, 2003), we chose to investigate the effects of the selective mGluR5 antagonist 3-((2-methyl1,3-thiazol-4-yl)ethynyl)pyridine (MTEP; Cosford et al, 2003) on methamphetamine reinforcement and reinstatement of methamphetamine-seeking behavior. Previous studies have suggested a significant role for this glutamate receptor subtype in self-administration of various drugs of abuse as well as the reinstatement of drug-seeking behavior (Chiamulera et al, 2001; Gass and Olive, 2008; Kenny and Markou, 2004; Olive, 2005).

\section{MATERIALS AND METHODS}

\section{Subjects}

All experimental procedures conformed to the $1996 \mathrm{NIH}$ Guide for the Care and Use of Laboratory Animals, the 2003 Guide for the Care and Use of Mammals in Neuroscience and Behavioral Research, and were conducted with the approval of an institutional animal care and use committee at the Medical University of South Carolina. Male SpragueDawley rats (250-350 g; Charles River Laboratories, Wilmington, MA, USA) were individually housed upon arrival. Animals were maintained on a $12 \mathrm{~h}$ light-dark cycle (lights off at 0600 hours) in a temperature- and humiditycontrolled animal facility. All experimentation was conducted during the dark phase of the light-dark cycle, with exception of $16 \mathrm{~h}$ overnight training and progressive ratio (PR) sessions that commenced near the end of the dark phase (at approximately 1600 hours) and continued through the light phase into the following morning (ending at approximately 0800 hours). Rats were given ad libitum access to food and water upon arrival until initial selfadministration training procedures. Thereafter, all groups of animals were given access to $20 \mathrm{~g}$ of food per day and $\mathrm{ad}$ libitum access to water (except during behavioral testing) so as to maintain consistent nutritional and metabolic states across all experimental groups (ie animals selfadministering food or methamphetamine). Food restriction was also imposed because we have previously noted that ad libitum access to food resulted in poor performance in operant food self-administration test sessions (unpublished observations).

\section{Apparatus}

Drug self-administration and reinstatement testing were conducted in operant self-administration chambers (ENV008; Med Associates, St Albans, VT, USA). Chambers were housed in melamine sound-attenuating cubicles equipped with a houselight and exhaust fan designed to mask external noise and odors, and was interfaced to a PC. Each chamber was equipped with two stainless-steel response levers located on one wall that flanked a $4.2 \times 5 \mathrm{~cm}$ food pellet receptacle. Each response lever was located approximately $7 \mathrm{~cm}$ above a stainless-steel rod floor, and positioned above each lever was a $2.5 \mathrm{~cm}$ diameter white stimulus light. Located near the top of the self-administration chambers was a Sonalert speaker that provided an auditory stimulus during drug delivery or cue-induced reinstatement procedures. Outside each chamber was a syringe pump that was interfaced to the computer and delivered the drug solution through a single-channel liquid swivel mounted atop the chamber by polyethylene tubing.

\section{Methamphetamine and Food Self-Administration}

Before self-administration training, rats were prepared with intravenous catheters into the jugular vein. Briefly, rats were anesthetized with isoflurane $(2 \% \mathrm{v} / \mathrm{v})$ vaporized in medical-grade breathing air at a flow rate of $0.41 / \mathrm{min}$, and the right jugular vein was isolated and a sterile silastic catheter filled with $100 \mathrm{U} / \mathrm{ml}$ heparin was inserted $2.5 \mathrm{~cm}$ into the vein. The catheter was secured to the surrounding tissue with sutures, and the opposite end of the catheter was tunneled subcutaneously to the dorsum where it exited the skin between the scapulae. This end of the catheter was secured to the surrounding tissue by sutures and a mesh collar attached to a threaded vascular access port (Plastics One, Roanoke, VA, USA). The access port was sealed with a piece of Tygon tubing closed at one end and a protective cap. Following surgical procedures, rats were allowed at least 5 days of recovery and received daily intravenous infusions of $70 \mathrm{U} / \mathrm{ml}$ heparin $(0.2 \mathrm{ml}$ volume) to maintain catheter patency and $100 \mathrm{mg} / \mathrm{ml}$ cefazolin $(0.1 \mathrm{ml}$ volume $)$ to protect against infection. Catheter patency was tested periodically throughout the experiment by infusion of $10 \mathrm{mg} / \mathrm{ml}$ sodium methohexital ( $0.2 \mathrm{ml}$ volume) and observation of brief loss of postural muscle tone. Rats that were to be tested for effects of MTEP on food self-administration, breakpoints for food reinforcement under a PR schedule, and cue-induced 
reinstatement of food-seeking behavior did not undergo catheter implantation.

After recovery from surgical procedures, all animals regardless of experimental group were limited to access to $20 \mathrm{~g}$ of food per day for the remainder of the experiment. To initiate operant responding, rats were placed in the selfadministration chambers for $16 \mathrm{~h}$ overnight training sessions whereby each press on the designated active lever delivered a $45 \mathrm{mg}$ food pellet (Bio-Serv, Frenchtown, NJ, USA) into the food receptacle on a fixed-ratio 1 (FR1) schedule of reinforcement. Each food pellet delivery was followed by a 20-s timeout period, during which additional active lever presses were recorded but produced no programmed consequences. Presses on the designated inactive lever were recorded but produced no consequences at any time during the experiment. Approximately $24 \mathrm{~h}$ following the initial overnight training session, rats were then placed into $2 \mathrm{~h}$ daily self-administration sessions whereby each press on the active lever resulted in delivery of methamphetamine $(0.1$ or $0.2 \mathrm{mg} / \mathrm{kg}$ per infusion, delivered in a volume of $0.06 \mathrm{ml}$ over a $2 \mathrm{~s}$ period), or a single $45 \mathrm{mg}$ food pellet, on an FR1 schedule of reinforcement. Each methamphetamine infusion or food pellet delivery was followed by a 20-s timeout period, during which additional active lever presses were recorded but produced no programmed consequences. Methamphetamine was delivered to the vascular access port by polyethylene tubing housed in a stainless-steel spring tether that was attached to the liquid swivel. Each methamphetamine infusion or food pellet delivery was accompanied by concurrent illumination of the stimulus light and presentation of an auditory stimulus $(\sim 65 \mathrm{~dB}, 2900 \mathrm{~Hz})$ for $2 \mathrm{~s}$. Selfadministration sessions were conducted 5 consecutive days per week, and each was preceded by intravenous infusion of $0.1 \mathrm{ml}$ of $70 \mathrm{U} / \mathrm{ml}$ heparin and followed by infusion of $0.1 \mathrm{ml}$ of $100 \mathrm{mg} / \mathrm{ml}$ cefazolin.

\section{Pharmacological Testing During Methamphetamine and Food Self-Administration}

To determine the effects of MTEP on active methamphetamine or food self-administration, each animal was allowed to self-administer methamphetamine $(0.1$ or $0.2 \mathrm{mg} / \mathrm{kg}$ per infusion, $n=10-11$ per group) or food pellets $(n=12)$ in $2 \mathrm{~h}$ daily sessions as described above until response patterns stabilized (ie the number of active lever presses per $2 \mathrm{~h}$ session varied less than $15 \%$ across two consecutive sessions, with a minimum of eight and a maximum twelve sessions). Next, animals were administered MTEP $(0.3,1$, or $3 \mathrm{mg} / \mathrm{kg}$, i.p.) or vehicle $10 \mathrm{~min}$ before the start of subsequent self-administration sessions in a randomized counterbalanced within-subjects design, with a maximum of two treatments being given per week and at least one treatment-free session being conducted between each drug administration to allow for washout of any drug effects. The primary dependent variables measured during each $2 \mathrm{~h}$ session were the number of active and inactive lever presses emitted, as well as the number of reinforcers delivered (ie methamphetamine infusions or food pellets).

\section{Pharmacological Testing Under a Progressive Ratio Schedule of Reinforcement}

To determine the effects of MTEP on the reinforcing efficacy of methamphetamine or food, separate groups of animals were trained to self-administer methamphetamine $(0.1$ or $0.2 \mathrm{mg} / \mathrm{kg}$ per infusion, $n=11$ per group) or food pellets $(n=12)$ in $2 \mathrm{~h}$ daily sessions under an FR1 schedule of reinforcement as described above for a minimum of 5 days. Next, animals were subject to PR schedules of reinforcement, where the number of lever presses required to obtain a single infusion of methamphetamine or delivery of a food pellet was determined by the following the equation: responses per reinforcer delivery $=5 \times e^{(\text {injection number } \times 0.2)}-5$ (ie $1,2,4,6,9,12$, $15,20,25,32,40$, etc) (Richardson and Roberts, 1996). All PR testing was conducted in $16 \mathrm{~h}$ overnight sessions, and each drug infusion or food pellet delivery was followed by a 20-s timeout period, during which additional active lever presses were recorded but produced no programmed consequences. Breakpoints were considered to be obtained when the animal emitted no lever responses for $1 \mathrm{~h}$. At least two baseline PR sessions were conducted before drug administration to establish baseline performance on the PR schedule of reinforcement. Ten minutes before subsequent PR test sessions, rats were administered MTEP $(0.3,1$, or $3 \mathrm{mg} / \mathrm{kg}$, i.p.) or vehicle in a randomized counterbalanced within-subjects design, with a maximum of two treatments being given per week and at least one treatment-free session being conducted between each drug administration to allow for washout of any drug effects. The primary dependent variables measured during each $16 \mathrm{~h}$ session were the number of active and inactive lever presses emitted, the number of reinforcers earned (methamphetamine infusions or food pellet deliveries), and the latency for each animal to reach its respective breakpoint.

\section{Pharmacological Testing During Reinstatement}

To determine the effects of MTEP on cue- and drug-induced reinstatement of methamphetamine-seeking behavior or cue-induced reinstatement of food-seeking behavior, separate groups of animals were allowed to self-administer methamphetamine $(0.1 \mathrm{mg} / \mathrm{kg}$ per infusion) or food pellets in $2 \mathrm{~h}$ daily sessions under an FR1 schedule of reinforcement as described above until response patterns stabilized (ie the number of active lever presses per $2 \mathrm{~h}$ session varied less than $15 \%$ across two consecutive sessions, with a minimum of eight and a maximum of twelve sessions). Next, all animals were subjected to extinction training, whereby presses on the active lever no longer produced any programmed consequences (ie no tone/light presentation and no activation of the syringe pump). Extinction training sessions were $2 \mathrm{~h}$ in length and were conducted until extinction criteria were met by all animals in each group (ie the number of active lever presses was $<20 \%$ than that observed during the final 2 days before commencement of extinction training). Next, animals were administered MTEP $(0.3,1$, or $3 \mathrm{mg} / \mathrm{kg}$, i.p.) or vehicle $10 \mathrm{~min}$ before cue- or drug-induced reinstatement testing procedures $(2 \mathrm{~h}$ each). For cue-induced reinstatement (Cue-Meth, $n=17$ or Cue-Food, $n=19$ ), each press on the active lever resulted in 
the presentation of the light-tone stimulus complex that was presented during active methamphetamine or food selfadministration as described above, as well as activation of the computer-controlled syringe pump in the Cue-Meth group; however, no drug solution or food pellet was delivered. For drug-induced reinstatement testing (DrugMeth, $n=11$ ), animals received a single injection of methamphetamine $(1 \mathrm{mg} / \mathrm{kg}$, i.p.) $30 \mathrm{~min}$ before the reinstatement test session, and during testing presses on the active lever resulted in no programmed consequences (ie no tone/light presentation and no activation of the syringe pump, so as to eliminate all cues that may have previously been associated with methamphetamine delivery). Following the first reinstatement test, animals underwent daily $2 \mathrm{~h}$ extinction sessions until extinction criteria were again obtained. This sequence was performed three times so that all animals received treatment with vehicle and two of the three doses of MTEP $(0.3,1$, and $3 \mathrm{mg} / \mathrm{kg}$, i.p.) in a randomized, counterbalanced within-subjects dose-response design. This 'crossover' design with one subset of animals always receiving vehicle treatment allowed for quantification of reinstatement magnitude during each test session by examining the behavior of vehicle-treated animals that were tested in parallel with MTEP-treated animals. The number of reinstatement tests was limited to a maximum of three per animal so as to avoid the diminution of reinstatement of drug- or food-seeking behavior due to the absence of delivery of the primary reinforcer (ie methamphetamine or food). The primary dependent variables measured during reinstatement testing were the number of active and inactive lever presses emitted.

\section{Drugs}

MTEP hydrochloride was obtained from Alexis Biochemicals (San Diego, CA, USA) and was dissolved by sonication in a vehicle consisting of $20 \% \mathrm{w} / \mathrm{v}$ 2-hydroxypropyl- $\beta$ cyclodextrin (Sigma-Aldrich, St Louis, MO), as it was found that MTEP was not readily soluble in water or saline. Injection volumes for MTEP were $1 \mathrm{ml} / \mathrm{kg}$ and were delivered by the intraperitoneal (i.p.) route. (+)Methamphetamine hydrochloride was obtained from Sigma-Aldrich and prepared in sterile $0.9 \%$ sodium chloride for intravenous infusion, or in the case of drug-induced reinstatement, was prepared at a concentration of $1 \mathrm{mg} / \mathrm{ml}$ in saline and administered i.p. in a volume of $1 \mathrm{ml} / \mathrm{kg}$. Doses of MTEP and methamphetamine are expressed as the weight of the salt.

\section{Statistical Analyses}

Data were analyzed using SigmaStat version 3.0 software (Systat Inc., San Jose, CA, USA). Effects of MTEP on the number of active lever presses, methamphetamine infusions delivered, or responding during the timeout period in the $2 \mathrm{~h}$ self-administration sessions were analyzed by a mixed two-way analysis of variance (ANOVA), with unit dose of methamphetamine reinforcement as a between-subjects factor and MTEP dose as a within-subjects factor. Effects of MTEP on the number of active lever presses for food, food pellets delivered, or responding during the timeout period were each analyzed by a one-way ANOVA. Effects of
MTEP on temporal patterns of active lever presses (in 15min time bins) during the $2 \mathrm{~h}$ self-administration sessions were analyzed by a two-way repeated-measures ANOVA, with MTEP dose and time bin as factors. For PR testing, separate two-way repeated-measures ANOVA were conducted on the number of methamphetamine reinforcers earned and the time to reach breakpoint, with unit dose of methamphetamine reinforcement as a between-subjects factor and MTEP dose as a within-subjects factor. A separate repeated-measures one-way ANOVA was conducted to determine effects of MTEP on the number of food reinforcers earned and the time to reach breakpoint for food reinforcement. Effects of MTEP on temporal patterns of active lever presses during the PR test sessions were analyzed by a two-way repeated-measures ANOVA, with MTEP dose and time bin as factors. Because the time to reach breakpoint varied greatly between all groups after the first $90 \mathrm{~min}$ of the PR session, we analyzed the first $90 \mathrm{~min}$ of each session in 15-min bins, and all subsequent responses were analyzed in a single time bin (ie $90+\mathrm{min}$ ). Cumulative response records were plotted for animals whose total number of active lever presses was at or within one standard deviation of the group mean.

For analysis of reinstatement testing, the number of active lever presses on the last 2 days of drug self-administration before extinction training was averaged to obtain a value for self-administration (SA). Values for extinction (Ext) represent the number of active lever presses on the last day of extinction training before the first reinstatement test session. Effects of MTEP on the number of active lever presses exhibited during reinstatement testing were compared against the respective group's Ext values using a oneway ANOVA. All inactive lever data were analyzed by either a mixed two-way ANOVA (for effects of MTEP in the fixed ratio and $\mathrm{PR}$ schedules of reinforcement) or by one-way ANOVA (in reinstatement testing). All ANOVAs were followed by pairwise Holm-Sidak multiple comparisons post hoc tests. $p<0.05$ was considered statistically significant for all tests performed. All data are presented as mean \pm SEM.

\section{RESULTS}

\section{Effects of MTEP on Methamphetamine and Food Self-Administration Under an FR1 Schedule of Reinforcement}

For the $2 \mathrm{~h}$ self-administration sessions conducted under an FR1 schedule of reinforcement, significant effects of MTEP dose on the number of active lever presses $\left(\mathrm{F}_{3,53}=6.43\right.$, $p<0.001)$ and the number of reinforcers delivered $\left(\mathrm{F}_{3,53}=8.21, p<0.001\right)$ were observed in the 0.1 and $0.2 \mathrm{mg} / \mathrm{kg}$ per infusion methamphetamine groups, and post hoc analysis revealed that the $3 \mathrm{mg} / \mathrm{kg}$ dose of MTEP significantly reduced the number of active lever presses and number of infusions delivered in each group (Figure 1a and c). A significant interaction between methamphetamine dose and MTEP dose was not observed with respect to active lever presses $\left(\mathrm{F}_{3,53}=2.05, p>0.05\right)$, suggesting that the effects of MTEP on the number of active lever presses was not dependent on the unit dose of methamphetamine. However, a significant interaction between methamphetamine 

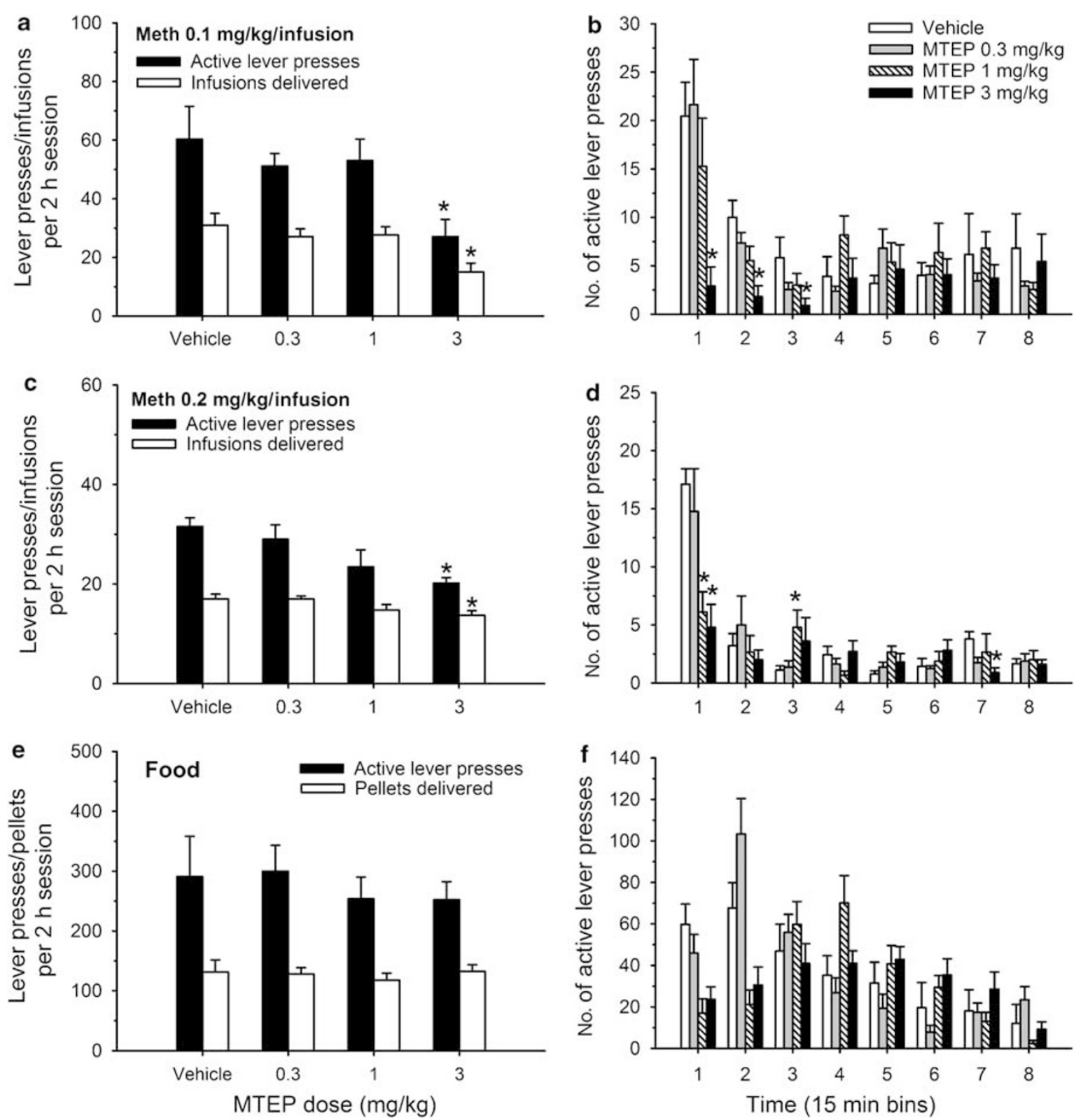

Figure I Effects of the type 5 metabotropic glutamate receptor (mGluR5) antagonist (MTEP) on self-administration of methamphetamine or food under a fixed-ratio I (FRI) schedule of reinforcement. Rats were trained to self-administer methamphetamine at $0.1 \mathrm{mg} / \mathrm{kg}$ per infusion $(\mathrm{a}, \mathrm{n}=1 \mathrm{I}), 0.2 \mathrm{mg} / \mathrm{kg}$ per infusion ( $c, n=10)$, or food pellets $(e, n=12)$ until response patterns stabilized. Vehicle or MTEP $(0.3$, 1 , or $3 \mathrm{mg} / \mathrm{kg})$ was given $10 \mathrm{~min}$ before $2 \mathrm{~h}$ selfadministration sessions. The number of active lever presses and infusions or pellets delivered is shown, whereas the number of inactive lever presses is presented in Table I. Panels b, d, and f show the temporal pattern of responding during the $2 \mathrm{~h}$ self-administration session in I5-min time bins. Asterisk (*) indicates data values are significantly different $(p<0.05)$ from those of vehicle-treated animals.

dose and MTEP dose was observed with respect to the number of methamphetamine infusions delivered $\left(\mathrm{F}_{3,53}=4.19, p<0.05\right)$, indicating that effects of MTEP on the number of infusions delivered were dependent on the unit dose of methamphetamine. In rats trained to selfadminister food (Figure 1e), no significant effects of MTEP dose on the total number of active lever presses $\left(\mathrm{F}_{3,32}=0.70, p>0.05\right)$ or the number of pellets delivered $\left(\mathrm{F}_{3,32}=0.41, p>0.05\right)$ were observed, indicating that MTEP did not alter overall food self-administration.

Analysis of the number of active lever presses made during the $20 \mathrm{~s}$ timeout period following each methamphetamine infusion (ie 'timeout responding') revealed a significant main effect of methamphetamine dose $\left(\mathrm{F}_{1,53}=11.85, p<0.005\right)$ and MTEP dose $\left(\mathrm{F}_{3,53}=4.18\right.$, $p<0.05)$, but no significant interaction between these two factors $\left(\mathrm{F}_{3,53}=0.84, p>0.05\right)$. Post hoc analysis revealed that MTEP at a dose of $3 \mathrm{mg} / \mathrm{kg}$ significantly reduced timeout responding in rats self-administering the $0.1 \mathrm{mg} / \mathrm{kg}$ per infusion but not the $0.2 \mathrm{mg} / \mathrm{kg}$ per infusion dose of methamphetamine (data not shown). MTEP did not alter timeout responding in rats self-administering food pellets $\left(\mathrm{F}_{3,32}=1.25, p>0.05\right)$ (data not shown). The number of inactive lever presses was also unaltered by MTEP (Table 1).

In rats self-administering the $0.1 \mathrm{mg} / \mathrm{kg}$ per infusion dose of methamphetamine, temporal analysis of the effects of 
Table I Effects of MTEP on Inactive Lever Presses During Methamphetamine or Food Self-Administration, Progressive Ratio Testing, and Reinstatement Testing

\begin{tabular}{|c|c|c|c|c|}
\hline & \multicolumn{4}{|c|}{ MTEP dose (mg/kg) } \\
\hline & 0 & 0.3 & $\mathbf{I}$ & 3 \\
\hline $0.1 \mathrm{mg} / \mathrm{kg} /$ infusion methamphetamine & $3.9 \pm 1.1$ & $3.8 \pm 0.8$ & $3.4 \pm 1.3$ & $1.7 \pm 0.8$ \\
\hline $0.2 \mathrm{mg} / \mathrm{kg} /$ infusion methamphetamine & I.I \pm 0.4 & $1.2 \pm 0.7$ & $0.6 \pm 0.5$ & $0.6 \pm 0.4$ \\
\hline \multicolumn{5}{|l|}{ Progressive ratio } \\
\hline $0.1 \mathrm{mg} / \mathrm{kg} /$ infusion methamphetamine & $24.4 \pm 6.3$ & $18.3 \pm 9.5$ & $32.4 \pm 17.9$ & $9.5 \pm 5.4$ \\
\hline $0.2 \mathrm{mg} / \mathrm{kg} /$ infusion methamphetamine & $190.0 \pm 75.2$ & $73.9 \pm 44.1$ & $195.5 \pm 94.5$ & $169.3 \pm \mid 40.1$ \\
\hline Food & $0.8 \pm 0.4$ & $0.6 \pm 0.3$ & $1.2 \pm 0.4$ & $2.2 \pm 1.0$ \\
\hline Cue-Food & $2.4 \pm 1.1$ & $1.7 \pm 0.7$ & $0.4 \pm 0.2$ & $0.4 \pm 0.3$ \\
\hline
\end{tabular}

MTEP, 3-((2methyl-I,3-thiazole-4-yl)ethynyl)pyridine.

All data are presented as mean \pm SEM. ANOVA revealed no significant effects of MTEP dose on inactive lever presses were found in any of the treatment groups (all p-values >0.05).

MTEP on the number of active lever presses in 15-min time bins revealed a significant effect of time bin $\left(\mathrm{F}_{7,210}=8.35\right.$, $p<0.001)$, MTEP dose $\left(\mathrm{F}_{3,210}=5.11, p<0.01\right)$, as well as an interaction between time bin and MTEP dose $\left(\mathrm{F}_{21,210}=2.76\right.$, $p<0.001)$. Post hoc analysis revealed that the number of active lever presses were reduced in the first three time bins in rats treated with the $3 \mathrm{mg} / \mathrm{kg}$ dose of MTEP as compared with vehicle-treated animals (Figure $1 \mathrm{~b}$ ). Likewise, in rats self-administering the $0.2 \mathrm{mg} / \mathrm{kg}$ per infusion dose of methamphetamine, temporal analysis of the effects of MTEP revealed a significant effect of time bin $\left(\mathrm{F}_{7,147}=15.89, \quad p<0.001\right), \quad$ MTEP dose $\quad\left(\mathrm{F}_{3,147}=5.38\right.$, $p<0.01)$, as well as an interaction between time bin and MTEP dose $\left(\mathrm{F}_{21,147}=3.46, p<0.001\right)$. Post hoc analysis revealed that the number of active lever presses was reduced in the first time bin in rats treated with the 1 and $3 \mathrm{mg} / \mathrm{kg}$ dose of MTEP compared with vehicle-treated animals (Figure 1d). However, rats treated with the $1 \mathrm{mg} / \mathrm{kg}$ dose of MTEP showed an increase in active lever presses during time bin 3 as compared with vehicle-treated animals. In rats self-administering food, temporal analysis of the effects of revealed a significant effect of time bin $\left(\mathrm{F}_{7,210}=15.92\right.$, $p<0.001)$ but no effect of MTEP dose $\left(\mathrm{F}_{3,210}=0.46\right.$, $p>0.05)$. However, a trend toward a reduction in the number of active lever presses for food was observed in the first two time bins in rats receiving the 1 or $3 \mathrm{mg} / \mathrm{kg}$ dose of MTEP.

Representative cumulative plots of the number of active lever presses during the $2 \mathrm{~h}$ self-administration sessions are presented in Figure 2. As can be seen, the $3 \mathrm{mg} / \mathrm{kg}$ dose of MTEP delayed the onset of responding for the $0.1 \mathrm{mg} / \mathrm{kg}$ per infusion dose of methamphetamine, and decreased the total number of responses emitted during the first $15 \mathrm{~min}$ time bin at both doses of methamphetamine. The $3 \mathrm{mg} / \mathrm{kg}$ dose of MTEP also appeared to attenuate the initial 'loading' phase of food self-administration during the first $1 \mathrm{~h}$ of the session as compared with vehicle-treated animals, but did not affect the overall number of responses.

\section{Effect of MTEP on Methamphetamine and Food Self- Administration Under a PR Schedule of Reinforcement}

Figure 3 shows the effects of MTEP treatment on responding for two doses of methamphetamine $(0.1$ and $0.2 \mathrm{mg} / \mathrm{kg}$ per infusion) or food under a PR schedule of reinforcement. A significant effect of methamphetamine dose $\left(\mathrm{F}_{1,60}=63.38\right.$, $p<0.001)$, MTEP dose $\left(\mathrm{F}_{3,60}=15.94, p<0.001\right)$, and an interaction between methamphetamine dose and MTEP dose $\left(\mathrm{F}_{3,60}=3.08, p<0.05\right)$ were observed with regard to total reinforcers earned. Post hoc analyses revealed that the $3 \mathrm{mg} / \mathrm{kg}$ dose of MTEP reduced the total number of reinforcers earned in both methamphetamine groups (Figure 3a). A significant effect of methamphetamine dose on time to reach breakpoint was observed $\left(\mathrm{F}_{1,60}=22.34\right.$, $p<0.001$ ), with animals self-administering $0.2 \mathrm{mg} / \mathrm{kg}$ per infusion requiring significantly more time to reach breakpoints as compared to the $0.1 \mathrm{mg} / \mathrm{kg}$ per infusion group. However, there was no effect of MTEP dose on time to reach breakpoint for either group $\left(\mathrm{F}_{3,60}=1.94, \quad p>0.05\right.$; Figure $3 b)$. In animals self-administering food, there was no effect of MTEP dose on the total number of reinforcers earned $\left(\mathrm{F}_{3,33}=1.33, p>0.05\right.$; Figure $\left.3 \mathrm{a}\right)$ or the time to reach breakpoint $\left(\mathrm{F}_{3,33}=0.53, p>0.05\right.$; Figure $\left.3 \mathrm{~b}\right)$. The number of inactive lever presses during $\mathrm{PR}$ testing was unaltered by MTEP (see Table 1).

Temporal analysis of responding under a PR schedule of reinforcement in animals self-administering the $0.1 \mathrm{mg} / \mathrm{kg}$ per infusion dose of methamphetamine revealed a significant effect of time bin $\left(\mathrm{F}_{6,180}=7.46, p<0.001\right)$, MTEP dose $\left(\mathrm{F}_{3,180}=2.82, p<0.05\right)$, but not an interaction 
Vehicle
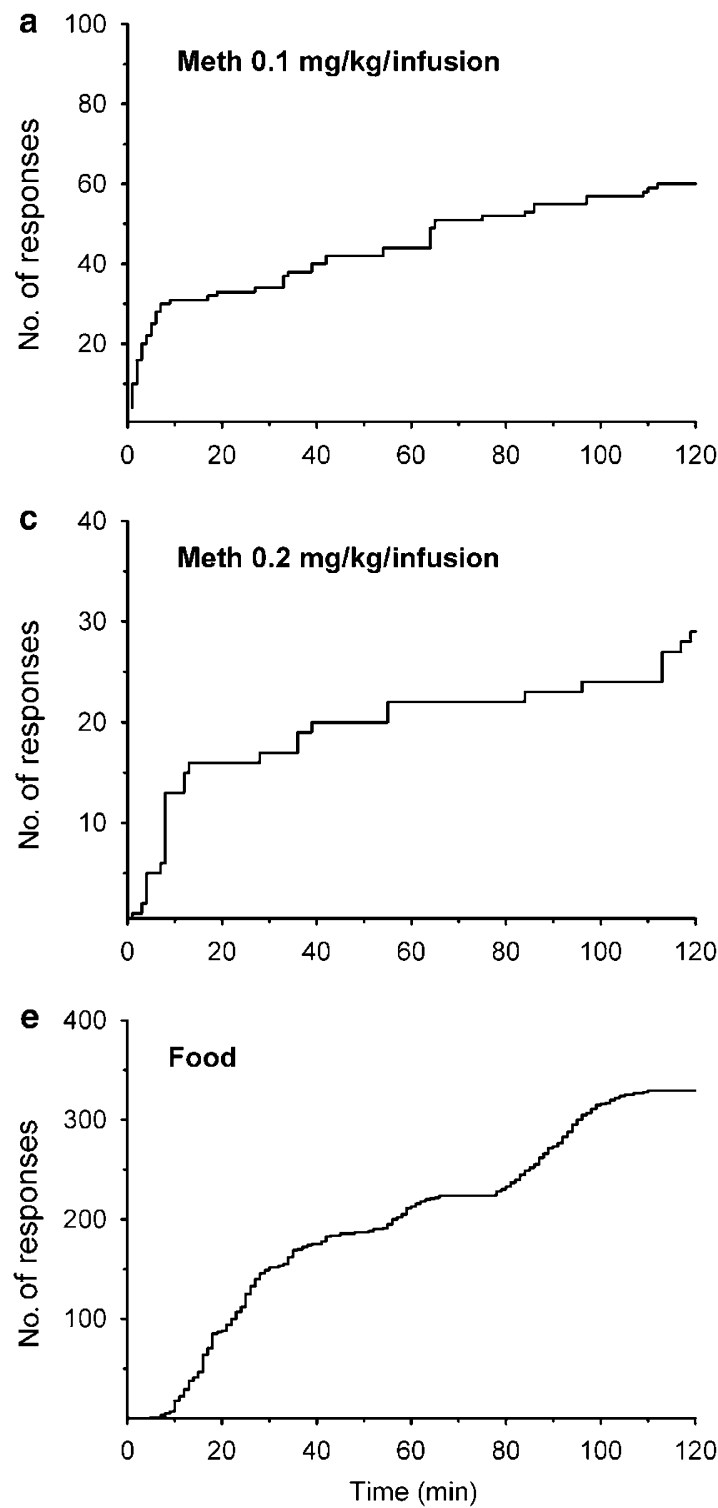

MTEP $3 \mathrm{mg} / \mathrm{kg}$
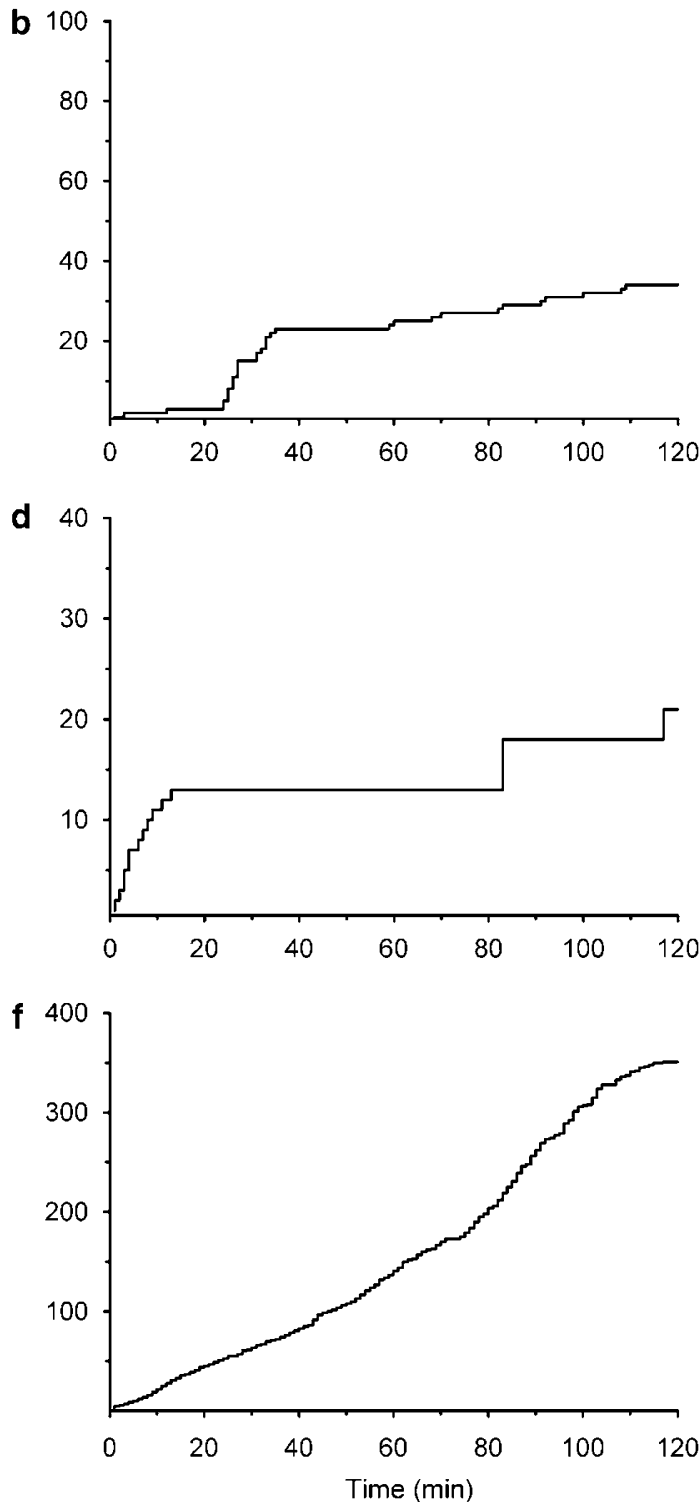

Figure 2 Representative cumulative response records from the $2 \mathrm{~h}$ fixed-ratio I (FRI) self-administration sessions in animals from each of the three experimental groups ( 0.1 or $0.2 \mathrm{mg} / \mathrm{kg}$ per infusion methamphetamine or food). Records were selected from animals treated with vehicle (panels a, $c$, and e) or $3 \mathrm{mg} / \mathrm{kg}$ MTEP (panels b, $d$, and f) whose total number of active lever presses was at or within one standard deviation of the group mean.

between these two factors $\left(\mathrm{F}_{18,180}=1.09, p>0.05\right)$. Post hoc analysis showed that the number of active lever presses was significantly reduced in animals treated with $3 \mathrm{mg} / \mathrm{kg}$ MTEP during the first six time bins but not during the remainder of the session (Figure 3c). In animals selfadministering the $0.2 \mathrm{mg} / \mathrm{kg}$ per infusion dose of methamphetamine, a significant effect of time bin $\left(\mathrm{F}_{6,180}=33.31\right.$, $p<0.001)$, MTEP dose $\left(\mathrm{F}_{3,180}=2.90, p<0.05\right)$, and an interaction between these two factors $\left(\mathrm{F}_{18,180}=2.50\right.$, $p<0.005)$ was observed. Post hoc analysis revealed that the number of active lever presses was significantly reduced in animals treated with $3 \mathrm{mg} / \mathrm{kg}$ MTEP during the first six time bins as well as during the remainder of the session (Figure 3d). In animals self-administering food, a significant effect of time bin $\left(F_{6,198}=45.33\right.$, $p<0.001)$ but not MTEP dose $\left(\mathrm{F}_{3,198}=0.80, p>0.05\right)$ was observed.

As seen in the representative cumulative plots in Figure 4, MTEP at a dose of $3 \mathrm{mg} / \mathrm{kg}$ appeared to delay the onset of responding as well as reduce the overall number of responses for both doses of methamphetamine in the PR test sessions. Despite the delayed onset and reduced overall active lever presses, animals treated with $3 \mathrm{mg} / \mathrm{kg}$ MTEP continued to respond for the same duration of time as vehicle-treated animals, and thus time to reach breakpoint was not altered. As under the FR1 schedule of reinforcement, MTEP appeared to attenuate the initial 'loading' phase of food self-administration during the first $1 \mathrm{~h}$ of the PR session as compared to vehicle-treated animals, but did not reduce the overall number of responses. 

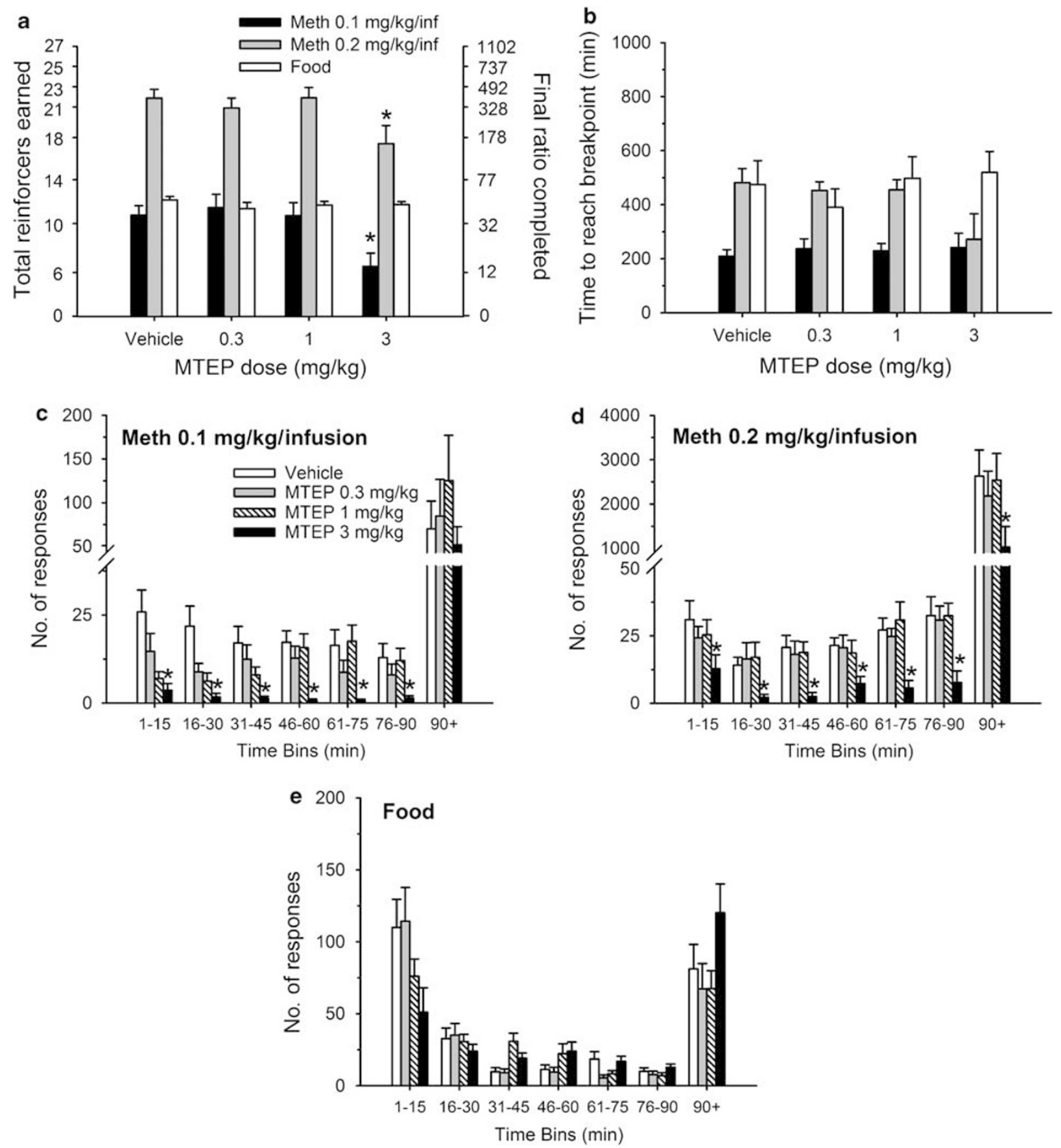

Figure 3 Effects of MTEP on self-administration of methamphetamine $(0.1$ or $0.2 \mathrm{mg} / \mathrm{kg}$ per infusion, $n=1 \mathrm{I}$ per group) or food pellets $(n=12)$ under a progressive ratio (PR) schedule of reinforcement. Vehicle or MTEP $(0.3,1$, or $3 \mathrm{mg} / \mathrm{kg}$ ) was given $10 \mathrm{~min}$ before $16 \mathrm{~h}$ overnight PR sessions. (a) The total number of reinforcers earned in the PR session is given along the left $y$ axis, and as a reference, the final ratio completed is given along the right $y$ axis. (b) Time taken to reach breakpoint, as defined by lack of any response emitted for I h. Panels $\mathrm{c}, \mathrm{d}$, and e show the temporal pattern of responding during the $2 \mathrm{~h}$ self-administration session for each group in 15 -min time bins for the first 90 min of the PR session as well as all responses emitted after the first 90 min ( $90+$ ). Inactive lever data are presented in Table I. Asterisk (*) indicates data values are significantly different $(p<0.05)$ from those of vehicle-treated animals.

\section{Effect of MTEP on Reinstatement of Methamphetamine- or Food-Seeking Behavior}

The effects of MTEP on the ability of drug-associated cues and drug priming to reinstate methamphetamine-seeking behavior, as well as the ability of food-associated cues to reinstate food-seeking behavior, are shown in Figure 5. During Cue-Meth reinstatement testing, a significant effect of MTEP dose on the number of active lever presses was observed $\left(\mathrm{F}_{4,59}=8.80, p<0.001\right)$, and post hoc analyses revealed that cue-exposed animals treated with vehicle or $0.3 \mathrm{mg} / \mathrm{kg}$ MTEP demonstrated reinstatement of methamphetamine-seeking behavior, as evidenced by a significant increase in the number of active lever presses as compared with Ext values. However, cue-exposed animals treated with 1 or $3 \mathrm{mg} / \mathrm{kg}$ MTEP failed to show reinstatement of 
Vehicle
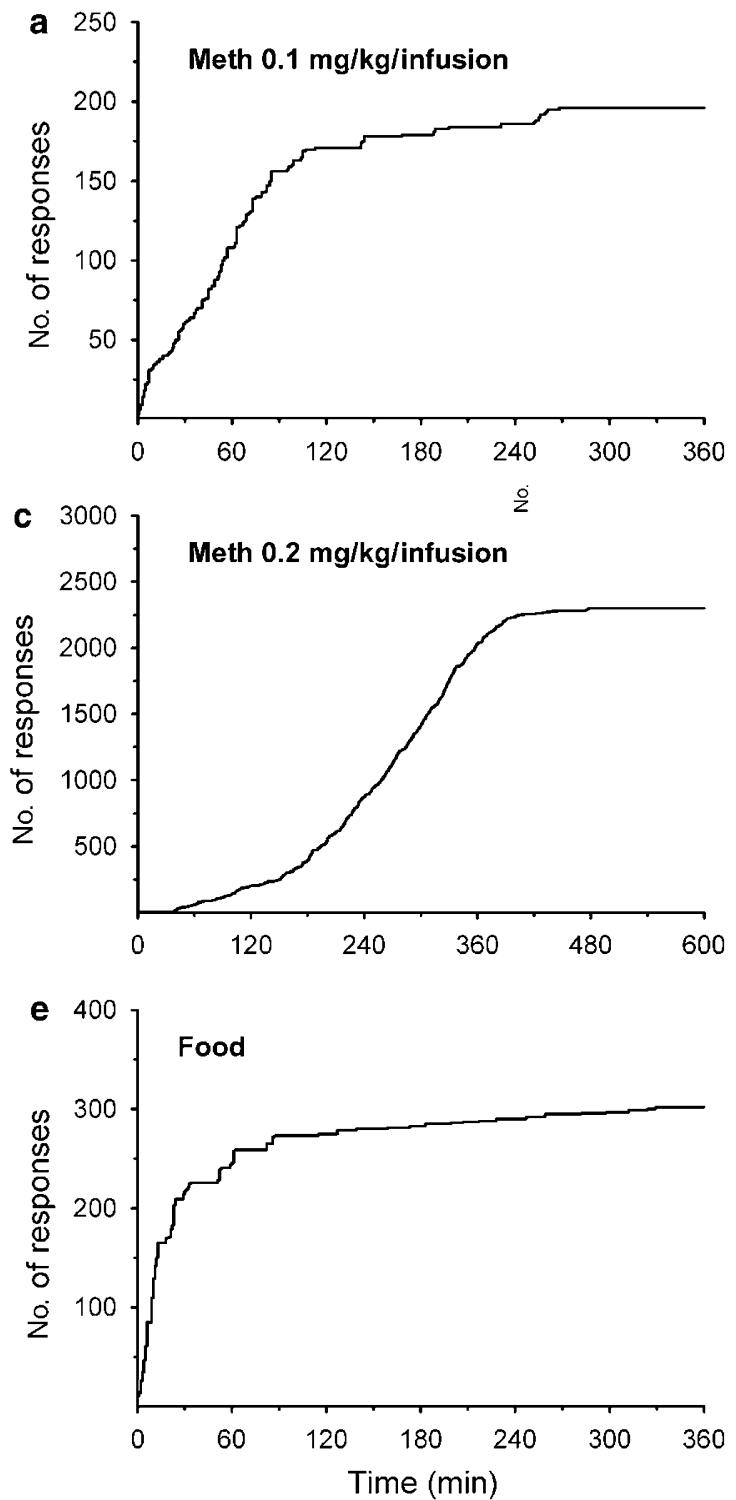

MTEP $3 \mathrm{mg} / \mathrm{kg}$
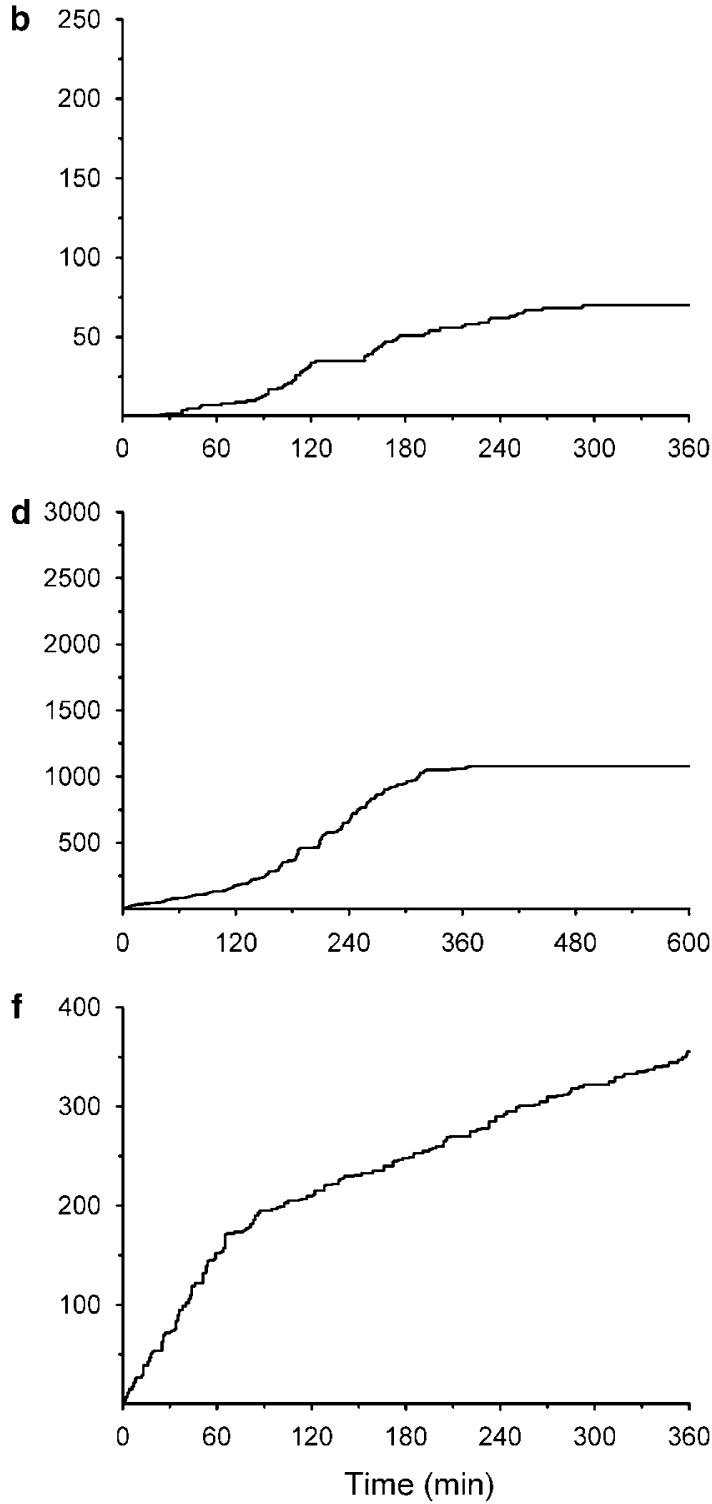

Figure 4 Representative cumulative response records from the progressive ratio (PR) sessions in animals from each of the three experimental groups ( 0.1 or $0.2 \mathrm{mg} / \mathrm{kg}$ per infusion methamphetamine or food). Records were selected from animals treated with vehicle (panels a, c, and e) or $3 \mathrm{mg} / \mathrm{kg}$ MTEP (panels $b, d$, and $f$ ) whose total number of active lever presses was at or within one standard deviation of the group mean. In panels $b$ and $f$, cumulative responses during the first $6 \mathrm{~h}$ of the PR session are shown, whereas in panel $\mathrm{d}$ cumulative responses during the first IO $\mathrm{h}$ of the PR session are shown.

methamphetamine-seeking behavior (Figure 5a). In addition, the number of active lever presses exhibited by these animals was significantly lower than that of vehicle-treated animals. During Drug-Meth reinstatement testing, a significant effect of MTEP dose on the number of active lever presses was observed $\left(\mathrm{F}_{4,41}=4.48, p<0.005\right)$, and post hoc analyses revealed that cue-exposed animals treated with vehicle or $0.3 \mathrm{mg} / \mathrm{kg}$ MTEP demonstrated reinstatement of methamphetamine-seeking behavior (Figure 5b). However, drug-exposed animals treated with 1 or $3 \mathrm{mg} / \mathrm{kg}$ MTEP failed to show reinstatement of methamphetamine-seeking behavior. In addition, the number of active lever presses exhibited by these animals was significantly lower than that of vehicle-treated animals. During Cue-Food reinstatement testing, all cue-exposed animals demonstrated a reinstate- ment of food-seeking behavior $\left(\mathrm{F}_{4,56}=3.41, p<0.05\right)$, and no significant effects of MTEP dose were observed (Figure 5c). The number of inactive lever presses during reinstatement testing was unaltered by MTEP treatment (see Table 1).

\section{DISCUSSION}

To our knowledge, the present studies are the first to demonstrate that mGluR5 receptors are involved in the reinforcing properties of methamphetamine as well as the reinstatement of methamphetamine-seeking behavior. We observed that administration of the selective mGluR5 antagonist MTEP dose dependently reduced intravenous methamphetamine self-administration on an FR1 schedule 

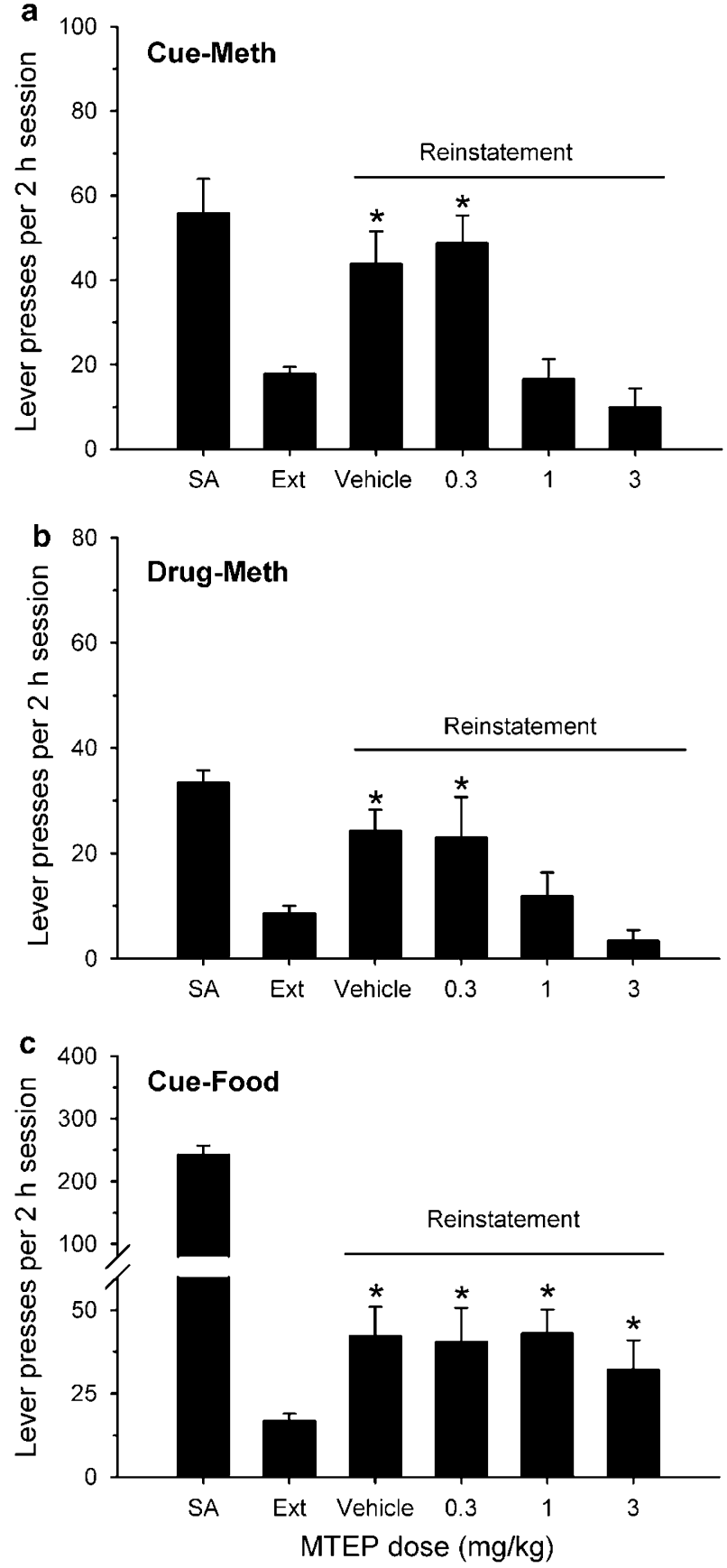

Figure 5 Effects of MTEP on the reinstatement of methamphetamine or food-seeking behavior. Rats were trained to self-administer methamphetamine at $0.1 \mathrm{mg} / \mathrm{kg}$ per infusion or food pellets before extinction and reinstatement procedures. Values for self-administration (SA) represent the average of the last 2 days of active drug or food self-administration before commencement of extinction training. Ext represents the total number of active lever presses exhibited on the last day of extinction training. (a) In the Cue-Meth group $(n=17)$, during reinstatement testing rats were exposed to response-contingent presentation of the light-tone stimulus that was paired with methamphetamine infusions during active methamphetamine self-administration. (b) In the Drug-Meth group $(n=I I)$, rats were given a single priming injection of methamphetamine ( $\mathrm{mg} / \mathrm{kg}$, i.p.) 30 min before reinstatement testing. (c) In the Cue-Food group $(n=19)$, during reinstatement testing rats were exposed to response-contingent presentation of the light-tone stimulus that was paired with food pellet delivery during active food self-administration. Asterisk $(*)$ indicates data values are significantly different $(p<0.05)$ from those in the Ext phase of the experiment of reinforcement at two unit doses of methamphetamine. These effects did not appear to be a result of nonspecific suppression of appetitive behaviors or motor function, as overall responding for food reinforcement under an FR1 or PR schedule of reinforcement was unaffected by all doses of MTEP tested. However, temporal analysis of effects of MTEP on food reinforcement revealed inhibitory effects during the first $30 \mathrm{~min}$ of the food self-administration session (see below), yet these effects were statistically nonsignificant. Our results support previous findings that mGluR5 receptors are important in the reinforcing effects of numerous drugs of abuse, as it has been shown previously that mice lacking mGluR5 receptors do not self-administer cocaine (Chiamulera et al, 2001), and selective mGluR5 antagonists reduce the self-administration of various drugs of abuse including cocaine (Chiamulera et al, 2001; Iso et al, 2006; Kenny et al, 2003; Lee et al, 2005; Paterson and Markou, 2005; Tessari et al, 2004), nicotine (Kenny et al, 2003; Paterson and Markou, 2005; Paterson et al, 2003; Tessari et al, 2004), and alcohol (Backstrom et al, 2004; Besheer et al, 2008; Cowen et al, 2005, 2007; Hodge et al, 2006; Lominac et al, 2006; Olive et al, 2005; Schroeder et al, 2005).

Temporal analysis of responding revealed that the effective dose of MTEP $(3 \mathrm{mg} / \mathrm{kg})$ in reducing methamphetamine-reinforced responding primarily exerted its inhibitory effects during the first $15-45 \mathrm{~min}$ of the $2 \mathrm{~h}$ selfadministration sessions. As the majority of responding for methamphetamine reinforcement occurred during this time period, it appears that MTEP reduced methamphetamine reinforcement by suppressing the initial burst of responding during the first period of access to the drug. The lack of effects of MTEP in reducing responding for methamphetamine during subsequent time bins is not likely due to a clearance of MTEP from the brain, as it has been demonstrated that a $3 \mathrm{mg} / \mathrm{kg}$ dose of MTEP produces $>75 \%$ occupancy of brain mGluR5 receptors for $2 \mathrm{~h}$ (Anderson et al, 2003). We also observed that MTEP reduced the number of active lever presses during the $20 \mathrm{~s}$ timeout period following each infusion of the $0.2 \mathrm{mg} / \mathrm{kg}$ per infusion dose of methamphetamine, but not in rats trained to self-administer food or the $0.1 \mathrm{mg} / \mathrm{kg}$ per infusion methamphetamine dose. The reasons for this differential ability of MTEP to reduce timeout responding are currently unclear, and need to be addressed in future studies employing different timeout period lengths and/or different response requirements for methamphetamine infusion (ie FR3 or FR5 schedules of reinforcement).

The ability of MTEP to reduce methamphetamine selfadministration and reinforcement may be a rate-dependent effect. The rate-dependency hypothesis (Dews, 1977; Sanger and Blackman, 1976) asserts that a psychoactive drug will increase the frequency of a certain behavior if the baseline levels of that behavior are low, whereas the opposite will be true for behaviors that are emitted at higher baseline rates. In the present study, under an FR1 schedule of reinforcement at methamphetamine doses of 0.1 and $0.2 \mathrm{mg} / \mathrm{kg}$ per infusion, vehicle-treated animals displayed an average response rate of approximately 0.5 and 0.25 active lever presses per min, respectively. In contrast, vehicle-treated animals responding for food reinforcement exhibited an average response rate of 2.5 active lever presses per min. As 
MTEP reduced overall responding primarily for methamphetamine, the effects of MTEP do not fit the traditional definition of a rate-dependent drug effect. However, the possibility remains that MTEP reduces responding only when response rates for a particular reinforcer are relatively low, and future studies are needed to determine if MTEP reduces responding for a nondrug reinforcer that produces response rates similar to those observed in the present study for methamphetamine reinforcement.

MTEP at a dose of $3 \mathrm{mg} / \mathrm{kg}$ also reduced responding for methamphetamine under a PR schedule of reinforcement, which is consistent with earlier studies demonstrating that the mGluR5 antagonist 2-methyl-6-(phenylethynyl)-pyridine (MPEP) reduces responding for cocaine, nicotine, or alcohol reinforcement under FR or PR schedules of reinforcement (cf Backstrom et al, 2004; Besheer et al, 2008; Chiamulera et al, 2001; Cowen et al, 2007; Hodge et al, 2006; Kenny et al, 2003; Lee et al, 2005; Paterson and Markou, 2005; Schroeder et al, 2005; Tessari et al, 2004). However, some investigators have found that certain pharmacological agents reduce responding for a drug reinforcer under FR or PR testing, and not both (Stafford et al, 1998). Our observations that MTEP attenuated methamphetamine self-administration under both FR and PR schedules of reinforcement underscores the notion that mGluR5 antagonism attenuates the reinforcing effects of this psychostimulant, and such ligands may be of potential clinical benefit in the treatment of methamphetamine addiction.

In contrast to the effects of MTEP on responding for methamphetamine under an FR1 schedule of reinforcement, in which observed effects appeared to be confined to the first $45 \mathrm{~min}$ of the session, more striking effects of MTEP on responding were observed under a PR schedule of reinforcement. Temporal analysis of responding during PR testing showed that the $3 \mathrm{mg} / \mathrm{kg}$ dose of MTEP suppressed the number of active lever presses during the first $90 \mathrm{~min}$ of the PR session when $0.1 \mathrm{mg} / \mathrm{kg}$ per infusion was used as the reinforcer, and suppressed responding throughout the PR test session when $0.2 \mathrm{mg} / \mathrm{kg}$ per infusion was used as the reinforcer. Thus, under a PR schedule of reinforcement, MTEP appears to exert a more dramatic and prolonged effect on methamphetamine reinforcement than under an FR1 schedule, suggesting pharmacological blockade of mGluR5 receptors may be more influential on drug self-administration behavior when response requirements for reinforcement are exponentially increased. However, MTEP did not alter the time to reach breakpoint, indicating that responding for methamphetamine (albeit reduced by MTEP) persisted for the same length of time as in vehicletreated animals. Thus, MTEP appears to reduce the reinforcing efficacy of methamphetamine as well as response rates without producing a premature cessation of responding.

MTEP did not alter overall responding for food under an FR1 or PR schedule of reinforcement. The former findings are consistent with findings of a previous study in which it was demonstrated that MPEP at doses up to $9 \mathrm{mg} / \mathrm{kg}$ did not alter food-maintained responding in rats (Paterson et al, 2003). However, these same investigators later reported that MPEP decreased breakpoints for food self-administration under a PR schedule of reinforcement (Paterson and
Markou, 2005), whereas in the current study we found no effect of MTEP on breakpoints for food reinforcement. These discrepant findings could be a result of the increased incidence of off-target effects of MPEP as compared with MTEP (Lea and Faden, 2006), as well as procedural differences between these two studies, such as the use of an FR5 schedule of reinforcement by Paterson and colleagues during self-administration training (as opposed to an FR1 in the present study) and the use of a different strain of rats (Wistar vs Sprague-Dawley rats in our study). Nonetheless, as shown in Figures if and 3e, MTEP appeared to reduce responding for food during the first 15-30 min of the FR1 and PR test sessions, although overall effects of MTEP dose throughout the session were not statistically significant. Thus, it is possible that under different experimental conditions, MTEP at similar doses might have inhibitory effects on food intake (see also Bradbury et al, 2005).

In the present study we also demonstrated that MTEP reduced cue- and drug-induced reinstatement of methamphetamine-seeking behavior, but had no effect on cueinduced reinstatement of food-seeking behavior. Other investigators have similarly shown that the mGluR5 antagonist MPEP also reduces cue- and/or drug-induced reinstatement of drug-seeking behavior (Backstrom and Hyytia, 2006; Backstrom et al, 2004; Bespalov et al, 2005; Lee et al, 2005; Tessari et al, 2004). In contrast to the effects of MTEP on methamphetamine reinforcement under FR1 and PR schedules of reinforcement, in which only the $3 \mathrm{mg} /$ $\mathrm{kg}$ dose was found to be effective, MTEP appeared to be more efficacious in preventing reinstatement of methamphetamine-seeking behavior, as effects at both the 1 and $3 \mathrm{mg} / \mathrm{kg}$ were observed. It is interesting to note that the magnitude of cue-induced reinstatement of food-seeking behavior that we observed was approximately $20 \%$ of values that were observed during active food self-administration before extinction training. However, regardless of treatment group, the magnitude of cue-induced reinstatement of foodseeking behavior was statistically significant when compared with those on the last day of extinction training. The reasons for this 'partial' reinstatement of food-seeking behavior induced by food-associated cues are currently unknown, and may likely reflect a weaker incentive salience of environmental cues associated with food as compared with those associated with methamphetamine. Similar 'partial' reinstatement of seeking of natural reinforcers such as food or sucrose elicited by environmental cues has been reported by other investigators (Bossert et al, 2006; Dravolina et al, 2007; Liechti et al, 2007; Liu et al, 2007; McLaughlin and Floresco, 2007).

MTEP selectively antagonizes the function of mGluR5 with an in vitro $\mathrm{IC}_{50}$ value of approximately $16 \mathrm{nM}$, and does not exhibit significant affinity for other mGluR subtypes (Cosford et al, 2003). In addition, unlike its predecessor MPEP, MTEP does not exhibit significant affinity for NMDA receptors, and thus is considered more selective for mGluR5 receptors than MPEP. Studies examining the displacement of selective mGluR5 radioligands in various species have shown that a $3 \mathrm{mg} / \mathrm{kg}$ dose of MTEP produces full occupancy of rat brain mGluR5 receptors within $5 \mathrm{~min}$ of i.p. administration, and that this receptor occupancy remains at $>75 \%$ for $2 \mathrm{~h}$ before declining to near $0 \%$ 
occupancy by $4 \mathrm{~h}$ postadministration (Anderson et al, 2003). Thus, the $3 \mathrm{mg} / \mathrm{kg}$ dose was chosen as the highest dose used in the present study. In addition, the terminal half-life of MTEP in plasma is approximately $8 \mathrm{~h}$ in rats (Green et al, 2006). In light of this moderate duration of action, we assessed the time to reach breakpoint in each $16 \mathrm{~h}$ PR test session to control for the possibility that the delay in onset of responding for methamphetamine produced MTEP would be countered by a post-drug elimination increase in responding for the reinforcer. However, we did not observe any increases in this parameter following administration of MTEP, suggesting that the drug did in fact decrease the reinforcing efficacy of methamphetamine.

The neurobiological mechanisms by which MTEP reduces methamphetamine reinforcement and reinstatement of methamphetamine-seeking behavior are unclear at this point and need to be further investigated. Although methamphetamine is a potent monoamine-releasing agent, its ability to potentiate glutamatergic neurotransmission has been documented (Abekawa et al, 1994; Bustamante et al, 2002; Nash and Maickel, 1999; Raudensky and Yamamoto, 2007; Rocher and Gardier, 2001; Shoblock et al, 2003; Stephans and Yamamoto, 1995). However, most of these studies have shown significant elevations in extracellular glutamate only after high doses of methamphetamine, and the increases observed tend to be delayed by at least $1 \mathrm{~h}$ following drug administration. Despite this, there is a small body of literature suggesting that glutamate transmission mediates the rewarding and reinforcing effects of methamphetamine. Pharmacological blockade of NMDA receptors with MK-801 inhibits the development of methamphetamine conditioned place preference (Kim and Jang, 1997), and the administration of the nonselective NMDA receptor antagonist dextromethorphan decreases intravenous methamphetamine self-administration (Glick et al, 2001; Jun and Schindler, 2000). Numerous studies have shown that mGluR5 receptors are functionally and biochemically linked to NMDA receptor function (cf Collett and Collingridge, 2004; Homayoun et al, 2004; Pisani et al, 2001; Ugolini et al, 1999), such that mGluR5 receptor activation enhances NMDA receptor function, and the reverse is true upon blockade of mGluR5 receptors. Given the aforementioned studies showing that NMDA antagonists reduce the rewarding and reinforcing effects of methamphetamine, it is possible that the ability of MTEP to reduce methamphetamine reinforcement may be secondary to reductions in NMDA receptor function. Additional studies examining the effects of disconnection of mGluR5 and NMDA receptor function are needed to examine this possibility.

A likely site of action of MTEP in reducing the reinforcing effects of methamphetamine as well as cue- and druginduced reinstatement is the nucleus accumbens, which expresses high levels of mGluR5 receptor mRNA and protein (Romano et al, 1995; Shigemoto and Mizuno, 2000; Shigemoto et al, 1993), and is a site where glutamate neurotransmission is critical for psychostimulant reinforcement and relapse (Baker et al, 2003; Cornish and Kalivas, 2000; Cornish et al, 1999; Di Ciano et al, 2001; McFarland et al, 2003; Pulvirenti et al, 1992; Schmidt et al, 2005). Recently, it has been demonstrated that microinjections of MPEP into the core of the nucleus accumbens attenuate cue-induced reinstatement of cocaine-seeking behavior (Backstrom and Hyytia, 2007). Similar studies utilizing site-specific microinjections are needed to confirm that mGluR5 receptors in this region mediate methamphetamine reinforcement and reinstatement of methamphetamineseeking behavior.

In conclusion, we have demonstrated that the selective mGluR5 antagonist MTEP attenuates the self-administration of methamphetamine as well as the reinforcing efficacy of this highly addictive drug under a PR schedule of reinforcement. MTEP also dose dependently prevented cueand drug-priming induced reinstatement of methamphetamine-seeking behavior. These results suggest that pharmacological agents that reduce mGluR5 receptor function may be a novel class of ligands that might be of clinical benefit in the treatment of methamphetamine addiction.

\section{ACKNOWLEDGEMENTS}

We thank Katherine Anderson and Kylie Dangerfield for their technical assistance in conducting the experiments, and Drs Ron See, Matthew Feltenstein and Jason Rogers for helpful suggestions on reinstatement procedures. Funding for this work was provided by PHS grant DA024355 from the National Institute on Drug Abuse to MFO. JTG was supported by a T32 Institutional Training Grant AA007474 from the National Institute on Alcohol Abuse and Alcoholism. Portions of the data described in this paper have been previously presented in abstract form (Osborne and Olive, in press).

\section{DISCLOSURE/CONFLICT OF INTEREST}

The authors do not have any conflicts of interest, financial or otherwise, that might bias this work.

\section{REFERENCES}

Abekawa T, Ohmori T, Koyama T (1994). Effects of repeated administration of a high dose of methamphetamine on dopamine and glutamate release in rat striatum and nucleus accumbens. Brain Res 643: 276-281.

Anderson JJ, Bradbury MJ, Giracello DR, Chapman DF, Holtz G, Roppe J et al (2003). In vivo receptor occupancy of mGlu5 receptor antagonists using the novel radioligand $\left[{ }^{3} \mathrm{H}\right]$-methoxy5-(pyridin-2-ylethynyl)pyridine). Eur J Pharmacol 473: 35-40.

Backstrom P, Hyytia P (2006). Ionotropic and metabotropic glutamate receptor antagonism attenuates cue-induced cocaine seeking. Neuropsychopharmacology 31: 778-786.

Backstrom P, Hyytia P (2007). Involvement of AMPA/kainate, NMDA, and mGlu5 receptors in the nucleus accumbens core in cue-induced reinstatement of cocaine seeking in rats. Psychopharmacology 192: 571-580.

Backstrom P, Bachteler D, Koch S, Hyytia P, Spanagel R (2004). mGluR5 antagonist MPEP reduces ethanol-seeking and relapse behavior. Neuropsychopharmacology 29: 921-928.

Baker DA, McFarland K, Lake RW, Shen H, Tang XC, Toda S et al (2003). Neuroadaptations in cystine-glutamate exchange underlie cocaine relapse. Nat Neurosci 6: 743-749.

Barr AM, Panenka WJ, MacEwan GW, Thornton AE, Lang DJ, Honer WG et al (2006). The need for speed: an update on methamphetamine addiction. J Psychiatry Neurosci 31: 301-313. 
Besheer J, Faccidomo S, Grondin JJ, Hodge CW (2008). Regulation of motivation to self-administer ethanol by mGluR5 in alcohol-preferring (P) rats. Alcohol Clin Exp Res 32: 209-221.

Bespalov AY, Dravolina OA, Sukhanov I, Zakharova E, Blokhina E, Zvartau E et al (2005). Metabotropic glutamate receptor (mGluR5) antagonist MPEP attenuated cue- and scheduleinduced reinstatement of nicotine self-administration behavior in rats. Neuropharmacology 49: 167-178.

Bossert JM, Poles GC, Sheffler-Collins SI, Ghitza UE (2006). The mGluR2/3 agonist LY379268 attenuates context- and discrete cue-induced reinstatement of sucrose seeking but not sucrose self-administration in rats. Behav Brain Res 173: 148-152.

Bradbury MJ, Campbell U, Giracello D, Chapman D, King C, Tehrani L et al (2005). Metabotropic glutamate receptor mGlu5 is a mediator of appetite and energy balance in rats and mice. J Pharmacol Exp Ther 313: 395-402.

Bustamante D, You ZB, Castel MN, Johansson S, Goiny M, Terenius L et al (2002). Effect of single and repeated methamphetamine treatment on neurotransmitter release in substantia nigra and neostriatum of the rat. $J$ Neurochem 83: 645-654.

Chiamulera C, Epping-Jordan MP, Zocchi A, Marcon C, Cottiny C, Tacconi $S$ et al (2001). Reinforcing and locomotor stimulant effects of cocaine are absent in mGluR5 null mutant mice. Nat Neurosci 4: 873-874.

Collett VJ, Collingridge GL (2004). Interactions between NMDA receptors and mGlu5 receptors expressed in HEK293 cells. $\mathrm{Br} \mathrm{J}$ Pharmacol 142: 991-1001.

Cornish JL, Kalivas PW (2000). Glutamate transmission in the nucleus accumbens mediates relapse in cocaine addiction. J Neurosci 20: RC89.

Cornish JL, Duffy P, Kalivas PW (1999). A role for nucleus accumbens glutamate transmission in the relapse to cocaineseeking behavior. Neuroscience 92: 1359-1367.

Cosford ND, Tehrani L, Roppe J, Schwieger E, Smith ND, Anderson J et al (2003). 3-[(2-Methyl-1,3-thiazol-4-yl)ethynyl]pyridine: a potent and highly selective metabotropic glutamate subtype 5 receptor antagonist with anxiolytic activity. $J$ Med Chem 46: 204-206.

Cowen MS, Djouma E, Lawrence AJ (2005). The metabotropic glutamate 5 receptor antagonist 3-[(2-methyl-1,3-thiazol-4yl)ethynyl)-pyridine reduces ethanol self-administration in multiple strains of alcohol-preferring rats and regulates olfactory glutamatergic systems. J Pharmacol Exp Ther 315: 590-600.

Cowen MS, Krstew E, Lawrence AJ (2007). Assessing appetitive and consummatory phases of ethanol self-administration in C57BL/ $6 \mathrm{~J}$ mice under operant conditions: regulation by mGlu5 receptor antagonism. Psychopharmacology 190: 21-29.

Darke S, Kaye S, McKetin R, Duflou J (2008). Major physical and psychological harms of methamphetamine use. Drug Alcohol Rev 27: $253-262$.

Dews PB (1977). Rate-dependency hypothesis. Science 198: 11821183.

Di Ciano P, Cardinal RN, Cowell RA, Little SJ, Everitt BJ (2001). Differential involvement of NMDA, AMPA/kainate, and dopamine receptors in the nucleus accumbens core in the acquisition and performance of pavlovian approach behavior. J Neurosci 21 : 9471-9477.

Dravolina OA, Zakharova ES, Shekunova EV, Zvartau EE, Danysz W, Bespalov AY (2007). mGlul receptor blockade attenuates cue- and nicotine-induced reinstatement of extinguished nicotine self-administration behavior in rats. Neuropharmacology 52: 263-269.

Gass JT, Olive MF (2008). Glutamatergic substrates of drug addiction and alcoholism. Biochem Pharmacol 75: 218-265.

Glick SD, Maisonneuve IM, Dickinson HA, Kitchen BA (2001). Comparative effects of dextromethorphan and dextrorphan on morphine, methamphetamine, and nicotine self-administration in rats. Eur J Pharmacol 422: 87-90.

Green MD, Yang X, Cramer M, King CD (2006). In vitro metabolic studies on the selective metabotropic glutamate receptor subtype 5 (mGluR5) antagonist 3-[(2-methyl-1,3-thiazol-4-yl) ethynyl]-pyridine (MTEP). Neurosci Lett 391: 91-95.

Hodge CW, Miles MF, Sharko AC, Stevenson RA, Hillmann JR, Lepoutre $\mathrm{V}$ et al (2006). The mGluR5 antagonist MPEP selectively inhibits the onset and maintenance of ethanol self-administration in C57BL/6J mice. Psychopharmacology 183: 429-438.

Homayoun H, Stefani MR, Adams BW, Tamagan GD, Moghaddam B (2004). Functional interaction between NMDA and mGlu5 receptors: effects on working memory, instrumental learning, motor behaviors, and dopamine release. Neuropsychopharmacology 29: 1259-1269.

Iso Y, Grajkowska E, Wroblewski JT, Davis J, Goeders NE, Johnson $\mathrm{KM}$ et al (2006). Synthesis and structure-activity relationships of 3-[(2-methyl-1,3-thiazol-4-yl)ethynyl]pyridine analogues as potent, noncompetitive metabotropic glutamate receptor subtype 5 antagonists; search for cocaine medications. J Med Chem 49: $1080-1100$

Jun JH, Schindler CW (2000). Dextromethorphan alters methamphetamine self-administration in the rat. Pharmacol Biochem Behav 67: 405-409.

Kalivas PW (2000). A role for glutamate transmission in addiction to psychostimulants. Addict Biol 5: 325-329.

Kalivas PW (2007). Cocaine and amphetamine-like psychostimulants: neurocircuitry and glutamate neuroplasticity. Dialogues Clin Neurosci 9: 389-397.

Kenny PJ, Markou A (2004). The ups and downs of addiction: role of metabotropic glutamate receptors. Trends Pharmacol Sci 25 265-272.

Kenny PJ, Paterson NE, Boutrel B, Semenova S, Harrison AA, Gasparini F et al (2003). Metabotropic glutamate 5 receptor antagonist MPEP decreased nicotine and cocaine self-administration but not nicotine and cocaine-induced facilitation of brain reward function in rats. Ann NY Acad Sci 1003: 415-418.

Kim HS, Jang CG (1997). MK-801 inhibits methamphetamineinduced conditioned place preference and behavioral sensitization to apomorphine in mice. Brain Res Bull 44: 221-227.

Lea PM, Faden AI (2006). Metabotropic glutamate receptor subtype 5 antagonists MPEP and MTEP. CNS Drug Rev 12: 149-166.

Lee B, Platt DM, Rowlett JK, Adewale AS, Spealman RD (2005). Attenuation of behavioral effects of cocaine by the metabotropic glutamate receptor 5 antagonist 2-methyl-6-(phenylethynyl)pyridine in squirrel monkeys: comparison with dizocilpine. J Pharmacol Exp Ther 312: 1232-1240.

Lee NK, Rawson RA (2008). A systematic review of cognitive and behavioural therapies for methamphetamine dependence. Drug Alcohol Rev 27: 309-317.

Liechti ME, Lhuillier L, Kaupmann K, Markou A (2007). Metabotropic glutamate $2 / 3$ receptors in the ventral tegmental area and the nucleus accumbens shell are involved in behaviors relating to nicotine dependence. J Neurosci 27: 9077-9085.

Lineberry TW, Bostwick JM (2006). Methamphetamine abuse: a perfect storm of complications. Mayo Clin Proc 81: 77-84.

Ling W, Rawson R, Shoptaw S, Ling W (2006). Management of methamphetamine abuse and dependence. Curr Psychiatry Rep 8: 345-354.

Liu X, Caggiula AR, Yee SK, Nobuta H, Sved AF, Pechnick RN et al (2007). Mecamylamine attenuates cue-induced reinstatement of nicotine-seeking behavior in rats. Neuropsychopharmacology 32: $710-718$.

Lominac KD, Kapasova Z, Hannun RA, Patterson C, Middaugh LD, Szumlinski KK (2006). Behavioral and neurochemical interactions between group I mGluR antagonists and ethanol: potential 
insight into their anti-addictive properties. Drug Alcohol Depend 85: $142-156$

Marshall JF, O’Dell SJ, Weihmuller FB (1993). Dopamineglutamate interactions in methamphetamine-induced neurotoxicity. J Neural Transm Gen Sect 91: 241-254.

Maxwell JC, Rutkowski BA (2008). The prevalence of methamphetamine and amphetamine abuse in North America: a review of the indicators, 1992-2007. Drug Alcohol Rev 27: 229-235.

McFarland K, Lapish CC, Kalivas PW (2003). Prefrontal glutamate release into the core of the nucleus accumbens mediates cocaineinduced reinstatement of drug-seeking behavior. J Neurosci 23: 3531-3537.

McLaughlin RJ, Floresco SB (2007). The role of different subregions of the basolateral amygdala in cue-induced reinstatement and extinction of food-seeking behavior. Neuroscience 146: 1484-1494.

Meredith CW, Jaffe C, Ang-Lee K, Saxon AJ (2005). Implications of chronic methamphetamine use: a literature review. Harv Rev Psychiatry 13: 141-154.

Nash JF, Maickel RP (1999). The role of the hypothalamicpituitary-adrenocortical axis in post-stress induced ethanol consumption by rats. Prog Neuropsychopharmacol Biol Psychiatry 12: 653-671.

Ohmori T, Abekawa T, Koyama T (1996). The role of glutamate in the neurotoxic effects of methamphetamine. Ann NY Acad Sci 801: 315-326.

Olive MF (2005). mGlu5 receptors: neuroanatomy, pharmacology, and role in drug addiction. Curr Psychiatry Rev 1: 197-214.

Olive MF, McGeehan AJ, Kinder JR, McMahon T, Hodge CW, Janak PH et al (2005). The mGluR5 antagonist 6-methyl-2(phenylethynyl)pyridine decreases ethanol consumption via a protein kinase Ce-dependent mechanism. Mol Pharmacol 67: 349-355.

Osborne MPH, Olive MF A role for mGluR5 receptors in intravenous methamphetamine self-administration. Ann $N Y$ Acad Sci (in press).

Paterson NE, Markou A (2005). The metabotropic glutamate receptor 5 antagonist MPEP decreased break points for nicotine, cocaine and food in rats. Psychopharmacology 179: 255-261.

Paterson NE, Semenova S, Gasparini F, Markou A (2003). The mGluR5 antagonist MPEP decreased nicotine self-administration in rats and mice. Psychopharmacology 167: 257-264.

Pisani A, Gubellini P, Bonsi P, Conquet F, Picconi B, Centonze D et al (2001). Metabotropic glutamate receptor 5 mediates the potentiation of $\mathrm{N}$-methyl-D-aspartate responses in medium spiny striatal neurons. Neuroscience 106: 579-587.

Pulvirenti L, Maldonado-Lopez R, Koob GF (1992). NMDA receptors in the nucleus accumbens modulate intravenous cocaine but not heroin self-administration in the rat. Brain Res 594: 327-330.

Raudensky J, Yamamoto BK (2007). Effects of chronic unpredictable stress and methamphetamine on hippocampal glutamate function. Brain Res 1135: 129-135.

Richardson NR, Roberts DC (1996). Progressive ratio schedules in drug self-administration studies in rats: a method to evaluate reinforcing efficacy. J Neurosci Meth 66: 1-11.

Rocher C, Gardier AM (2001). Effects of repeated systemic administration of d-Fenfluramine on serotonin and glutamate release in rat ventral hippocampus: comparison with methamphetamine using in vivo microdialysis. Naunyn Schmiedebergs Arch Pharmacol 363: 422-428.
Romano C, Sesma MA, McDonald CT, O’Malley K, Van den Pol AN, Olney JW (1995). Distribution of metabotropic glutamate receptor mGluR5 immunoreactivity in rat brain. J Comp Neurol 355: $455-469$.

Sanger DJ, Blackman DE (1976). Rate-dependent effects of drugs: a review of the literature. Pharmacol Biochem Behav 4: 73-83.

Schmidt HD, Anderson SM, Famous KR, Kumaresan V, Pierce RC (2005). Anatomy and pharmacology of cocaine priming-induced reinstatement of drug seeking. Eur J Pharmacol 526: 65-76.

Schroeder JP, Overstreet DH, Hodge CW (2005). The mGluR5 antagonist MPEP decreases operant ethanol selfadministration during maintenance and after repeated alcohol deprivations in alcohol-preferring (P) rats. Psychopharmacology 179: $262-270$.

Shigemoto R, Mizuno N (2000). Metabotropic glutamate receptors-immunocytochemical and in situ hybridization analysis. In: Ottersen OP, Storm-Mathisen J (eds). Handbook of Chemical Neuroanatomy: Metabotropic Glutamate Receptors: Immunocytochemical and In Situ Hybridization Analyses. Elsevier: London. pp 63-98.

Shigemoto R, Nomura S, Ohishi H, Sugihara H, Nakanishi S, Mizuno N (1993). Immunohistochemical localization of a metabotropic glutamate receptor, mGluR5, in the rat brain. Neurosci Lett 163: 53-57.

Shoblock JR, Sullivan EB, Maisonneuve IM, Glick SD (2003). Neurochemical and behavioral differences between d-methamphetamine and d-amphetamine in rats. Psychopharmacology 165: 359-369.

Srisurapanont M, Jarusuraisin N, Kittirattanapaiboon P (2001). Treatment for amphetamine dependence and abuse. Cochrane Database Syst Rev CD003022.

Stafford D, LeSage MG, Glowa JR (1998). Progressive-ratio schedules of drug delivery in the analysis of drug selfadministration: a review. Psychopharmacology 139: 169-184.

Stephans SE, Yamamoto BK (1994). Methamphetamine-induced neurotoxicity: roles for glutamate and dopamine efflux. Synapse 17: 203-209.

Stephans SE, Yamamoto BY (1995). Effect of repeated methamphetamine administrations on dopamine and glutamate efflux in rat prefrontal cortex. Brain Res 700: 99-106.

Sulzer D, Sonders MS, Poulsen NW, Galli A (2005). Mechanisms of neurotransmitter release by amphetamines: a review. Prog Neurobiol 75: 406-433.

Tata DA, Yamamoto BK (2007). Interactions between methamphetamine and environmental stress: role of oxidative stress, glutamate and mitochondrial dysfunction. Addiction 102: 49-60.

Tessari M, Pilla M, Andreoli M, Hutcheson DM, Heidbreder CA (2004). Antagonism at metabotropic glutamate 5 receptors inhibits nicotine- and cocaine-taking behaviours and prevents nicotine-triggered relapse to nicotine-seeking. Eur J Pharmacol 499: 121-133.

Tzschentke TM, Schmidt WJ (2003). Glutamatergic mechanisms in addiction. Mol Psychiatry 8: 373-382.

Ugolini A, Corsi M, Bordi F (1999). Potentiation of NMDA and AMPA responses by the specific mGluR5 agonist CHPG in spinal cord motoneurons. Neuropharmacology 38: 1569-1576.

Vocci FJ, Appel NM (2007). Approaches to the development of medications for the treatment of methamphetamine dependence. Addiction 102: 96-106.

Winslow BT, Voorhees KI, Pehl KA (2007). Methamphetamine abuse. Am Fam Physician 76: 1169-1174. 